\title{
STORM VAN 'S GRAVESANDE.
}

\author{
VOORDRACHT OP 30 MAART 1921 VOOR HET PROVINCIAAI. \\ GENOOTSCHAP VOOR KUNSTEN EN WETENSCHAPPEN EN \\ DE PLAATSELIJKE AFDEELING VAN HET ALGEMEEN NEDER- \\ LANDSCH VERBOND TE 'S HERTOGENBOSCH GEHOUDEN \\ DOOR J. A. J. DE VILLIERS.
}

De naam „Essequebo", die in verschillende vormen gegeven wordt in de vroegste geschriften, wordt in verband met Nederlandsche ondernemingsgeest het eerst genoemd in de „Verclaring van de onbekende ende onbeseylde Voiage van America", gedaan en beschreven in de jaren 1597 en 1598 door Anton Cabeljau.

Cabeljau, die Commies-Generaal van deze reis was, noemt „Dessekebe” als een der rivieren stroomende tusschen Corentine en Orinoco die voorbij gevaren werden zonder andere nasporingen, ,deur dijen onsen tijt seer verloopen ende datter nijet veel te halen en was, zoo ons d'indianen wijs maecten". Cabeljau's reis gaf aanleiding tot een petitie aan de Staten-Generaal, houdende verzoek Guiana te mogen koloniseeren. Wanneer aan dat verzoek voor het eerste gevolg werd gegeven is thans misschien niet uit te maken, doch het schijnt zeker dat particuliere onderneming voorafging aan het officiëele optreden dat belichaamd werd in den patentbrief aan de Nederlandsche West-Indische Compagnie verleend in 1621 .

Over den juisten datum van de eerste nederzetting te Essequebo is scherp van gedachten gewisseld, doch het is waarschijnlijk een dier vraagstukken die nooit zullen worden opgelost. De eenige bepaalde mededeeling dienaangaande is vervat in een handschrift uit de pen van Majoor John Scott, aardrijkskundige van Karel II, omstreeks 1669, welk stuk de stichting toeschrijft aan Groenewegen, die in of kort na 1616 zou hebben opgericht „een fort op een klein eiland, 30 mijl opwaarts de rivier Disseekeeb, en dat uitzicht gaf in twee groote zijtakken van die beroemde rivier". Dit is blijkbaar eene beschrijving van de plaats van Fort Kijk-overal, dat ongeveer een eeuw lang het middelpunt was der Nederlandsche nederzetting. 
Deze mededeeling vindt ook eenigermate bevestiging in een handschrift van 1624, hetwelk aangeeft dat er in dien tijd in Essequebo een nederzetting bestond, die al eenige jaren daar geweest was. Dit belangwekkende verhaal van de „Voyage faict par les Pères de Familles" bevat eene juiste mededeeling van den ingang tot de rivier Essequebo en een schetskaart van de ankerplaats (dicht bij de plek waar het Fort Kijk-overal zich bevond), welke geen twijfel laat aan de juiste kennis dier ligging; het verhaal bevat eveneens aanteekeningen die getuigen van een vroegere bekendheid met het district en omtrent eene reeds bestaanden handel.

De mededeelingen in dit reisverhaal worden na een korte tusschenruimte gevolgd door eenige losse, doch zeer besliste aanteekeningen die aantoonen dat in dien tijd reeds een geregeld Hollandsch Bestuur in een of anderen vorm aan de Essequebo gevestigd was, en dat dit reeds lang genoeg had bestaan om een zeer gewoon en bekend onderwerp te zijn. In elk geval was spoedig na 1630 de Nederlandsche nederzetting te Essequebo een beslist feit geworden in de geschiedenis der Nieuwe Wereld, en al zij het slechts vaag, wij kunnen dan reeds door voorkomende verwijzingen naar den gang van zaken en beheerders der nederzetting haar innerlijke ontwikkeling volgen.

In 1704 werd geboren Laurens Storm van 's Gravesande, de man onder wiens langdurig bewind de Kolonie, zooals wij die kennen, werd ontwikkeld, en het begin der $18 \mathrm{e}$ eeuw brengt de verste uitbreiding van de invloeds-sfeer der Nederlanders, die haar basis had in Essequebo. Geen verdere pogingen der Nederlanders, geen nieuwere onderzoekingen der Engelschen, hebben iets toegevoegd aan het gebied dat beheerd werd door den Commandeur Samuel Beekman.

Storm's taak was te verwezenlijken, vast te leggen, een vast begrip te geven aan de beteekenis van landbezit. Het was weggelegd voor de Engelschen der 19e eeuw meerdere juistheid te geven aan dit gebied en ten slotte de grenzen der kolonie met volkomene juistheid aan te geven. Maar de vage grenzen die de Essequebo nederzetting van 1704 bepaalden waren slechts minder gedefinieerd dan de hedendaagsche grenslijn; in sommige opzichten strekten zij veel verder dan deze.

In dien tijd was de Kolonie Essequebo gelegen om Fort Kijk-overal, hetwelk stond op het eiland waar de Essequebo met Massaruni en Cuyuni samenvloeit; aan den hoofdoever dier rivieren, bij de samenvloeiing, lagen eenige plantages der Compagnie 
en enkele behoorende aan particulieren; de bebouwing zette zich vrij langzaam voort, stroomafwaarts langs de Essequebo tot de eilanden in hare monding. Oostwaarts bevond zich feitelijk geen andere nederzetting dichterbij dan Berbice, en de Demeraryrivier was nog niet voor verkeer geopend. Westwaarts strekte zich de invloedsfeer der Nederlanders langs de kust uit tot aan de monding der Orinoco en binnenlands ook tot dicht bij deze rivier; feitelijk mag gezegd worden, dat die invloedsfeer het geheele gebied tusschen de Essequebo en de Orinoco omvatte. Zuidwaarts bestond rivieropwaarts langs de Essequebo toentertijd géén vestiging, doch de handelaren der Compagnie waren wel gewoon stroomopwaarts te gaan tot aan den mond der Rupununi, en ook over land tot een hooger punt aan deze rivier gelegen, waar langs zij hun weg vonden naar de savannahs gelegen tusschen Guiana en de Amazonenrivier, en vermoedelijk zelfs nog zuidelijker.

Zoodanig waren de grenzen die geacht mogen worden den Nederlanders te zijn aangewezen bij het bijzonder Verdrag van Utrecht, dat in 1714 hen eindelijk geheel en al beschermde tegen de aanvechtingen van de Spanjaarden.

Onder de officiëele stukken, die een eeuw later in het bezit van Groot-Britannië kwamen toen Essequebo en Demerary in 1814 aan dit Rijk werden overgedragen, bevonden zich de rapporten naar het moederland gezonden door de hoogere ambtenaren der Nederlandsch West-Indische Compagnie, en van het allergrootste belang in die rapporten is de serie geschreven door Storm van 's Gravesande, een man zoo totaal vergeten, zelfs in zijn eigen land, in de 19e eeuw, dat generaal Netscher, in zijn „Geschiedenis van de Koloniën Essequebo, Demerary en Berbice", van hem spreekt als een dier verdienstelijke Nederlanders, „wier namen weinig of niet bekend zijn en die toch verdienen aan de vergetelheid ontrukt te worden".

Het geheel van Storm's brieven, loopende over een tijdperk van 34 jaar - van 1738 tot 1772 - zou 21 deelen, van 300 octavo bladzijden ieder, vullen.

Met nauwgezette zorg en in uitvoerige bijzonderheden schreef Storm elken dag over de gewone gebeurtenissen in het leven der Kolonie. De schepen die aankomen van en vertrekken naar Zeeland; de ladingen die zij aanbrengen; de voorraden die hij noodig heeft; de producten naar het vaderland gezonden; de behaalde handelswinsten; de verliezen geleden door gewaagde onderne- 
mingen; de toestand van de plantages der Compagnie; de handelingen der Compagnie dienaren, van den dominé en den dokter; politiequaesties van burgerlijk recht; de haarkloverijen van verschillende personen - bijzonderheid na bijzonderheid, die het leven eener nederzetting maken - dat alles vindt men terug in de brieven van den Directeur-Generaal en allen getuigen van de grootste belangstelling op allerlei gebied.

Bij het openbaar maken van een betrekkelijk klein deel uit die brieven was het de bedoeling niet de geschiedenis der Kolonie te schrijven of weder te schrijven. Het uitmuntende en uitvoerige werk van Netscher kan niet gemakkelijk worden overtroffen. Maar Storm's brieven waren Netscher onbekend en Storm's leven omvat een zeer belangrijke, zij het dan ook betrekkelijk korte periode uit de geschiedenis der Kolonie, en al kan dan ook niet gesproken worden van eenige uitzetting, de jure, van de grenzen van het uitgestrekte gebied aan zijn bewind toevertrouwd, toch bereikte Essequebo onder Storm het toppunt van zijn welvaart onder Nederlandsch beheer, en onder zijn bestuur werd de stichting der Kolonie Demerary feitelijk begonnen. Door zijn onvermoeide geestkracht werden onbevolkte plaatsen bevolkt; door zijn taktische scherpzinnigheid werden de wilde stammen onderworpen; door zijn vaderlandsliefde werden zijn hem-benijdende en oorlogzuchtige buren op een afstand gehouden. Zoo dan al niet de jure, was er zeker gebiedsuitbreiding de facto.

De man, wiens brieven een afspiegeling geven van het derde eener eeuw in de geschiedenis van Essequebo en Demerary, was geen man van den gewonen stempel, en toch behoorde hij tot een soort gewoon genoeg in de Nederlanden van dien tijd. Het gemeenebest, uitgeput door langdurige, kostbare en bloedige oorlogen, was, aan het begin der $18 \mathrm{e}$ eeuw, snel in aanzien dalende in den rang van groote Europeesche mogendheid, en de mannen, in wier aderen het bloed der Geuzen vloeide, werden natuurlijk kregelig bij die onbeduidende binnenlandsche twisten en voelden zich de handen jeuken om nieuwe landen en volken te veroveren, zooals hun vaderen dat hadden gedaan in het roemrijk verleden van hun land.

Laurens Storm van 's Gravesande stamde uit een oud geslacht, welks leden van vader op zoon zitting hadden gehad in den Raad van Delft sedert het jaar 1270. Juist een eeuw vóór de geboorte van den toekomstigen Directeur-Generaal werd zijn overgrootvader, Laurens, in die stad geboren, in 1605, doch ves- 
tigde zich al spoedig te 's-Hertogenbosch, waar hij verschillende gemeentelijke betrekkingen vervulde, van 1640 tot 1685 . Dirk, Laurens' derde zoon, geboren in 1646, volgde zijn vader in deze en meer belangrijke ambten op, en uit Dirk's gezin van tien kinderen dienen er hier drie vermeld te worden.

De eerste was Pieter, geboren in 1683; hij bekleedde gelijke ambten als zijn vader en stierf in 1721. Hij huwde in 1703 met Alpheda Louisa van Luchtenburg (toen in haar 17e jaar) en die in 1711 overleed. De oudste van hun kinderen was Laurens, de schrijver van onze brieven.

De tweede zoon van Dirk was Ewoud Hendrik, oom van onzen Laurens, geboren 1684 en overleden 1750; hij volgde zijn vader in tenminste één van diens betrekkingen op, en huwde in 1722 Johanna Charlotta, door Rietstap beschreven als „Barones Boyd van Kilmarnock, geboren te 's-Hertogenbosch in 1694, gestorven 1781, dochter van Jacob, kapitein van een compagnie Schotten, n dienst van dezen staat". Uit deze echtvereeniging zijn gesproten al de jonkheeren Storm van 's Gravesande, die thans in Nederland leven.

De derde was Willem Jacob, een andere oom van onzen held; hij liet den bijnaam Storm vallen, werd geboren in 1688, overleed 1742, verwierf een doctorsgraad in 1707 en trad in 1715 op als Secretaris van een Gezantschap door de Staten-Generaal naar Groot-Brittannië gezonden om George I geluk te wenschen bij zijn troonsbestijging. Zijn uitmuntende gave als wiskundige deed hem de vriendschap verwerven van vele geleerde Engelschen, onder wie genoemd mogen worden Bisschop Burnet en Sir Isaac Newton, terwijl de „Royal Society” hem inschreef onder haar leden. Hij werd hoogleeraar in de sterrekunde en wiskunde aan de Leidsche Hoogeschool op zijn 29e aar en nam achtereenvolgens de leerstoelen in voor burgerlijke en militaire bouwkunde en wijsbegeerte, terwijl hij uitnoodigingen, tot hem gericht door Peter I en Frederik II in 1724 en 1740 om een plaats in te nemen aan Russische en Pruisische Hoogescholen, van de hand wees. Voltaire, die hem persoonlijk leerde kennen, sprak van hem als le profond 's Gravesande. Zijn werken verwierven hem een wereldberoemden naam en werden in 1774 gezamenlijk uitgegeven, met een levensbericht als inleiding. door Professor Allamand, Rector der Leidsche Universiteit wiens naam af en toe in Storm's brieven aangetroffen wordt.

Zoo waren de voorvaderen en verwanten van den man die 
voorbestemd was zulk een beteekenisvolle rol te spelen in het westelijk deel van het koloniaal gebied van zijn land, in streken, die, ofschoon slechts schaars bevolkt, zulk een toekomst beloofden, dat zij opwekten de afgunst van den trotschen Spanjaard en den naijver van den hardwerkenden Brit, en de invloed dier twee volken - vaak dringend in de hoogste mate - heeft een groote rol gespeeld in het leven van den Directeur-Generaal.

Geboren te 's-Hertogenbosch op den 12en October 1704 trad Laurens Storm van 's-Gravesande op zijn 17e jaar in het leger, vermoedelijk als een wat kort-aangebonden jongeling, want in zijne brieven gewaagt hij telkens van zijn gewone openhartigheid en in zijn latere leven spreekt hij van een twist dien hij in 1730 had met den vader van zijn stiefmoeder, Adriaan van Bronkhorst, Burgemeester van Utrecht, in de volgende bewoordingen:

„Ik ben van een oude Hollandsche famielje oorspronkelijk, een geboore Bossenaar, maar altoos goed rond goed Zeeuwsch geweest, voor niemand bevreesd.

„... Ik hebbe altoos mijn werk gemaekt van de oude Hollandsche opregtheyd te volgen .... in mijn ruim 17 jaarige militairen dienst altoos voor de vuyst te werk gegaan, noyt ontsien mijn opperhoofden (echter met verschuldigde eerbied) opregt de waarheyd te seggen sonder omweegen; hier door heb ik haare agting verworven en heb nog den brief leggen van mijn oude 82 jaarige Colonel den Generaal van Pallant, wanneer zijn Excellentie kennis gaff van mijn resolutie om naar Essequebo te gaen en bedankte voor alle genotene weldaden, mij d' eer aandeed te schrijven dat hem mijn avancement hartelijk lieff en aangenaam was maar teffens hem seer leed deed eene sijner beste officieren te verliesen. Wijlen Syne Doorluchtige Hoogheyd (Willem IV) hoog loffelijker gedagtenisse de moeyte wel hebbende willen neemen alle mijne brieven aan U.E.G.A. te leesen (dit moet in 1750 geweest zijn), deed mij d'eer aan te seggen "UE. is nog al den ouden Storm van 's-Gravesande, Jan Regtuyt", doelende op het geval dat ik 20 jaaren te vooren in Utrecht daar S. D. H. studeerde met mijn stieffgrootvader den Borgermeester van Bronkhorst S. D. aangaende gehad hebbe waardoor mijn avancement onder de voet wierp daar bij tvoegende „was UE. hier gebleven was UE. immers nu een van onse Generaels"."”

En dus verkoos Storm, toen hij het leger verliet, de WestIndische Compagnie in haar kolonie Essequebo te dienen als secretaris en boekhouder en legde als zoodanig te Middelburg den eed af in October 1737. Van dien tijd af zou hij gehoorzaamheid hebben te betoonen jegens een lichaam van bewindhebbers, die hem somtijds jarenlang buiten de middelen lieten om hun instructies uit te voeren; zou hij genoodzaakt zijn gehoorzaamheid af te dwingen van slecht gevoede, onwillige slaven, van zelfzuchtige en niet-loyale kolonisten. 
In 1729 was Storm in den echt getreden met Lumea Con stantia van Bercheyck, en uit dit huwelijk sproten tien kinderen, van welke zeven werden geboren vóór het gezin naar Essequebo vertrok en waarvan er toen vijf in leven waren, terwijl van die tien slechts zes den volwassen leeftijd bereikten. Van deze waren vier jongens, waarvan er drie onder hun vader dienden en vóór hem overleden, en de beide dochters, in de Nederlanden geboren, waren ook, gelijk de Directeur-Generaal erkent, niet-officiëel in den dienst der Compagnie, die niet genoeg mannelijk personeel had, werkzaam gesteld.

Op hoogen prijs stellende de hartelijke gelukwenschen van zijn kolonel bij zijne bevordering tot zijne nieuwe betrekking, ging de jonge soldaat daarmede naar zijn nieuw tehuis, want al legde hij ook den soldatenrok af, Storm was toch vóór alles door en door soldaat. Het eerste onderwerp dat hij behandelde in zijn eersten brief naar het vaderland betrof niet suiker of verschepingen - de twee zaken, die den bewindhebbers het meeste belang inboezemden en die hem later zooveel moeilijkheden zouden veroorzaken - doch betrof den toestand der bezetting. En dat hij na de mannen zijn aandacht schonk aan de forten was natuurlijk, en met dien vaderlandslievenden ijver en gemis aan zelf-interesse, die al zijne daden kenmerkten, bood Storm dadelijk aan de voltooiing van het nieuwe fort op Vlaggen-eiland onder zijn toezicht tè nemen, misschien wel als een ontspanning van zijn meer secretarieele plichten, die, alhoewel vermoedelijk vervelend, toch stiptelijk en met ijver nagekomen werden.

De voltooiing van het fort in een betrekkelijk korten tijd, in aanmerking nemende de moeilijkheden ondervonden om arbeidskrachten en materialen te krijgen, was voor Storm en de kolonisten een groote voldoening, doch de bezetting is hem tot het einde van zijn bewind toe steeds een droeve last gebleven. Zonder een voldoende macht was het zelfs onmogelijk de slaven in bedwang te houden, laat staan de Spaansche indringers af te weren, en jaar op jaar zien wij hoe Storm er bij de Bewindhebbers tot vervelens toe op aandringt versterkingen uit te zenden van degelijke, goedgeoefende mannen. Nevens al die pogingen en hetgeen tot zijn gewone werkzaamheden behoorde, had Storm handelsen mijn-ontginnings-expedities georganiseerd, die de verst-strekkende gevolgen zouden hebben voor de kolonie, en had bovendien reeds het plan - want hij had zelf de peilingen in de rivier gedaan - tot het stichten der nieuwe nederzetting in Demerary. Zulk een belanglooze ijver kon niet lang onbeloond blijven. 
Commandeur Gelskerke overleed den 16 Juli 1742 en de Raden der Kolonie, den buitengewonen ijver en de werkzaamheid door den Secretaris betoond, op prijs stellende, benoemden hem voorloopig tot Commandeur, ondertusschen nadere orders uit het vaderland verbeidende; de benoeming werd in Zeeland bevestigd op den 13 April 1743.

Van dien tijd af zijn Storm's brieven steeds meer belangwekkend, doch het is mijn voornemen niet meer te doen dan in breede trekken de aandacht te vestigen op Storm's politiek betreffende die zaken, welke de ontwikkeling der Kolonie raken.

Het kan gezegd worden dat het krachtig bevestigen van de macht in de kolonie Essequebo het hoofdpunt is in Storm's gouverneurschap en op drie wijzen spiegelt zich dat duidelijk af in zijn brieven:

ten eerste, door de besliste stappen gedaan om de bezittingen der Nederlanders krachtig vast te leggen door een goed doordachte politiek van ontwikkeling en ontginning;

ten tweede, in de politiek, gevolgd jegens de verschillende Indiaansche stammen, die Storm in het bezit vond van het binnenland en kustgebied.;

ten derde - en dit is misschien het aller-belangrijkste - in de besprekingen omtrent de grensbepalingen en Storm's krachtige verdediging van de rechten der Nederlanden tegenover de Spanjaarden.

Van Storm's meesterlijke onderzoekingsplannen wil ik slechts één voorbeeld geven, doch een heel belangrijke, want het heeft een plaats gevonden in de geschiedkundige aardrijkskunde.

Slechts een jaar na Storm's aankomst in de Kolonie werd een zekere Nicolaas Horstman, een Duitsch geneesheer in dienst van de West-Indische Compagnie, de Essequebo opgezonden, om een doorgang te vinden naar de Amazonen-rivier, om tegelijkertijd handel te drijven met de inboorlingen, en, indien mogelijk, de beroemde, maar fabelachtige stad El Dorado te ontdekken, gelegen aan het eveneens fabelachtige meer Parima.

De waterscheiding overstekend tusschen Essequebo en de Amazone, vond Horstman de werkelijke oorsprong van de fabel van het Gouden Meer, evenals Schomburgk hem honderd jaar later opnieuw ontdekte - het was slechts een klein meer, Amucu geheeten, hetwelk af en toe zijn oevers overstroomde en een groot moeras vormde.

Toen hij de Rio Negro bereikt had, ging Horstman naar de Portugeezen over en bleef bij hen; daar ontmoette hij La Con- 
damine en overhandigde dien reiziger een kopie van de kaart van het land dat hij doorgereisd was, en deze kaart, korrekt in haar algemeene trekken, was de eerste waaruit aardrijkskundigen de ware gedaante van het land tusschen de Amazone en Essequebo gewaar werden. La Condamine overhandigde haar aan d'Anville, een bekenden kaartenmaker van de 18e eeuw, en onder zijn handen werd zij de basis gemaakt van een in het algemeen nauwkeurige schets van dit gedeelte van het land in de eerste groote kaart van Zuid-Amerika, in 1748 uitgegeven.

Humboldt verwijst dikwijls naar Horstman's kaart in zijn „Voyage aux régions équinoxiales”.

Storm's politiek tegenover de inboorlingen getuigde over het algemeen van breede opvatting en verlichting: in zoover deze zich kenmerkte door eigen belang, bewees zij ontegenzeggelijk dat dit eigen belang samenging met het algemeen belang der Indiaansche stammen - het was voor dien tijd een vooruitstrevende politiek. In 1750, toen Storm met verlof in Europa toefde, maakte hij voor de Bewindhebbers der West-Indische Compagnie een afzonderlijk rapport, dat een merkwaardig verstandig standpunt aangeeft van zijn algemeene Indiaansche politiek. Terwijl hij de Indianen behandelt als natuurlijke vrienden en bondgenooten der Nederlanders, legt hij krachtig den nadruk op de dwaasheid vuurwapenen te geven in de handen der inboorlingen; zijn aanteekeningen en beweringen dienaangaande zijn volkomen gelijk aan die, welke in de laatste halve eeuw gemaakt zijn door Britsche beheerders in Afrika. Evenmin verloor hij uit het oog het gevaar dat de mededinging van naburige koloniën zijn breeder kijk zou kunnen tegenwerken, evenals GrootBritannië in West-Afrika onder de oogen heeft te zien den afkeer van Fransche en Duitsche kooplieden om zich te onderwerpen aan een politiek door allen in theorie als juist beaamd.

In ruwe trekken is Storm's algemeen denkbeeld op dit punt nedergelegd in een korten zin in een der brieven van 1762, waarin hij zegt:

„Soo lange wij het geluk mogen hebben wel te staan met d'Indiaenen, waer toe alle mijne pogingen aenwende en deselve de hand boven het hoofd houde en voor onderdrukking bewaere, soo lang seg ik hebben wij geen nood",

en hiermede kunnen wij vergelijken de uiteenzetting zijner politiek, zooals die door hem wordt gegeven in een brief van 1769, tegen het einde van zijn bewindschap: 
„Is er iemand die het nutter en noodzaekelijker acht de vriendschap der Indiaenen voor de Colonie, zoo ben ik het E. G. A. Heeren, want zoo lange wij zoo gelukkig zijn deselve om ons te hebbe woonen, zoo zijn wij veijlig binnens land en hebbe niets te vreesen, waeromme ik ook niet naelaete, door al wat mij mogelijk is derselver vriendschap te cultiveeren en haer tegens alle mishandelingen en dwingelandije der blanken voor te staen (zoo veel als het de gevoegelijkheid toelaet), waerdoor ik mij onder haer zoo bemind hebbe gemaekt dat ik tegenswoordig van haerlieden alles kan bekome wat begeere, en selfs aen d'Arrowacken (om haer te attacheeren aen deese Colonie en het verhuijsen nae de Berbice met de komst van den nieuwen Gouverneur te belette), gegeeven een Commandeur tot haer lieder genoegen, waer onder sij nu alle staen die tusschen deese revier en Berbice woonen".

Het gevolg van die juist aangegeven politiek toonde zich ten tijde van een gevaarlijken opstand onder de slaven van Berbice. Deze opstand uitte zich feitelijk het krachtigst in een kolonie waarvoor Storm in geen enkel opzicht verantwoordelijk was; doch gevaar voor Berbice deed gevaar ontstaan voor Demerary en Essequebo en daarom stelde Storm zijn geheele bezetting ter beschikking om Berbice tot het uiterste te beschermen. Hij riep de hulp der Indianen in uit elk deel der kolonie. Hij zette Caribben en Arrowakken in beweging door geheel Essequebo, van de Rupununi en de Cuyuni tot de Corentine en de Abari, en aan dit belangrijke gebruik maken van Indiaansche hulp met goeden uitslag mag de veiligheid der zuster-kolonie zeker worden toegeschreven. In de brieven krijgen wij een uitmuntende beschrijving van het gebruik maken der opgeroepen inboorlingen en Storm kon zelfs niet nalaten dienaangaande uitdrukking te geven aan zekere verbazing en bewondering.

Aan het slot van deze korte uiteenzetting van Storm's Indiaansche politiek mag opgemerkt worden dat de gevolgen daarvan nawerkten tot op onzen tijd. De Indianen vroegen in de volgende eeuw van de Britten dezelfde voordeelen en bondgenootschap, die zij onder de Nederlanders hadden genoten, en daaraan werd gaarne gevolg gegeven.

Over het algemeen kan zeker getuigd worden dat het de diplomatieke kant van Storm's beheer is die als de meest belangwekkende en misschien meest belangrijke dient te worden beschouwd.

Storm's nasporingen aangaande de grenzen der kolonie onder zijn beheer staande, en zijn handhaven van de rechten der Nederlandsche Compagnie tegen de aanvallen daarop door de Spanjaarden, waren terzelfder tijd de grondslag en de hoeksteen van zijn pogen de kolonie vast teleggen als een aardrijkskundig geheel. Het is onmogelijk het belang te overschatten die zijn brieven had- 
den in het jongste grensgeschil tusschen Britsch Guiana en Venezuela. Even goed als zijn nauwkeurige handelspolitiek en zijn Indiaansche politiek de aardrijkskundige uitgestrektheid der kolonie Britsch Guiana bepaalden, evengoed gaven zijn krachtige afwijzing der Spaansche eischen en zijn krachtige aandrang op de verantwoordelijkheid der Nederlandsche Compagnie tot hun uiterste grenzen den wettelijken grondslag waarop de Britten hun aanspraken grondden op hun eenige Zuid-Amerikaansche kolonie.

Storm's gouverneurschap moet daarom steeds levendige belangstelling hebben voor de Britten, als zijnde het tijdperk dat de tegenwoordige kolonieBritsch Guiana tot een mogelijkhe dmaakte. Het is hoogst waarschijnlijk dat zonder zulk een man als Storm, die een vaste politiek nastreefde, de Bewindhebbers der WestIndische Compagnie de zaken totaal aan hun lot zouden hebben overgelaten. Het was verleidelijk voor den Gouverneur alles op te offeren aan de oogenblikkelijke voordeelen der Bewindhebbers of aan de eischen der binnenlandsche speculanten. In groote mate kreeg later een dergelijke politiek de overhand en stelde deze de resultaten van Storm's langdurig beheer in groot gevaar. Doch Storm, een man van ontwikkeling, met denkbeelden en begrip van belangen veel verder reikende dan de onmiddellijke eischen van het oogenblik, hield voor oogen een prachtig begrip van hetgeen de kolonie zou kunnen zijn en worden, voor zoover dat in zijn macht lag, en latere verwaarloozing vermocht niet den goeden grondslag te ondermijnen door hem gelegd. Toen eindelijk, 150 jaren na hem, het vraagstuk omtrent de ware uitgestrektheid der kolonie moest uitgevochten worden voor een internationale rechtbank, waren het het werk en de brieven van den ouden Storm die zulk een krachtigen steun gaven aan de opvolgers der Nederlanders. In waarheid kan de geschiedenis van Britsch Guiana nooit van dat werk worden gescheiden.

In de eerste jaren van zijn beheer waren Storm's brieven bij lange na niet zoo talrijk als later het geval was, maar er is nauwelijks één brief door den Commandeur geschreven, die den lezer niet in nauwer kennis brengt met den $\mathrm{m}$ a $\mathrm{n}$. Hoewel soldaat was zijn streven steeds den vrede te bewaren - vrede binnen en op zijn grenzen - en voor hem waren vrede en eendracht gelijk met de vreeze Gods. De „rustelooze geesten”, die reeds spoedig zijn pogen vruchteloos maakten, waren vermoedelijk de ,goddelooze lasteraars", waarover hij zich in 1745 zoo bitter beklaagde. Deze hadden blijkbaar het oor getroffen van de Bewindhebbers 
in Zeeland, wier onwaardige behandeling van den Commandeur, gepaard aan hun bijna misdadige verwaarloozing van de kolonie, wat betreft de aanvoeren, spoedig Storm's diensten voor hem zoo bitter deden zijn, want reeds in December 1746 vraagt hij in de meest dringende bewoordingen zijn ontslag, welk verzoek acht maanden later herhaald werd.

Evenwel, een verhooging van zijn salaris (de eenige verhooging, die hij ooit van de Compagnie kreeg), de aanstelling van zijn tweeden zoon tot assistent, en het geschenk van een neger met vrouw en kind (dien Storm uit humaniteitsbegrippen had aangeboden te koopen) - al deze bewijzen van goedgunstigheid vergezeld van een verklaring hoe zeer Bewindhebbers zijn diensten op prijs stelden - verzoenden hem weder eenigen tijd met zijn ambt. Doch slechts voor korten tijd, want reeds in Maart 1749 was Storm „overtuigd dat het van het grootste belang zou zijn" zijn lastgevers ,een volledig woordelijk rapport uit te brengen" en dus vroeg hij verlof naar Europa. Dat verlof werd toegestaan, doch het toestaan er van was niet juist gezien, want Storm's twee jaren lange afwezigheid uit een kolonie, waar goddeloosheid en onbetrouwbaarheid tierden, bleek een te groote eisch voor het handhaven van hetgeen hij aan autoriteit bezat. Het aanbieden aan de Vergadering te Middelburg van een uitvoerig opgesteld rapport moge Bewindhebbers al overtuigd hebben van Storm's ijver en ernst, het had niettemin weinig practische gevolgen. De Commandeur, uitstekend ontvangen door den opper-bevelhebber, Willem IV, Prins van Oranje, die pas kort te voren gekozen was als Gouverneur-Generaal der West-Indische Compagnie, door Graaf Willem Bentinck, den patroon van Essequebo en Demerary, en door andere grootheden, werd verheven tot den rang van Directeur-Generaal en zijn oudste zoon werd begiftigd met het Commandeurschap der pas gestichte nederzetting Demerary, doch de Compagnie maakte tevens van de gelegenheid gebruik aan te dringen op hetgeen wordt aangeduid als hun ,groote hervorming", nl. een stelsel van misplaatste bezuiniging - voor het eerst in 1744 ter sprake gebracht - een stelsel dat Storm later vaak rondweg ten sterkste afkeurde als verderfelijk voor de kolonie, iets wat het inderdaad bleek te zijn.

$\mathrm{Na}$ een laatste afscheid te hebben genomen van al zijn vrienden in de Nederlanden, aangezien er voor hem geen enkel belang kon bestaan ooit weer daarheen te gaan, keerde Storm naar de kolonie terug, waar hij zijn invloed zéér verzwakt vond. Adriaan Spoors, de secretaris - een bekwaam doch onhandelbaar man, dien de 
Commandeur zelf, toen hij zijn ambt aanvaard had, voor die betrekking had aanbevolen, doch met wien hij nooit op erg vriendschappelijken voet schijnt te zijn geweest - had, vermoedelijk als een verlenging van zijn tijdelijk beheer gedurende Storm's afwezigheid, de officieele directie gekregen, c on j u n ctim met den Directeur-Generaal, over de plantages der Compagnie. Dit hinderde Storm, want bijaldien dit zijn verantwoordelijkheid verminderde, moest het ook vaak leiden tot verschil van meeningen. De planters daarenboven beschouwden het hoofd der kolonie, meer nog sedert zijn bezoek aan het moederland, als de spreektrompet der compagnie die hun belangen verwaarloosde en slechts haar eigen voordeel zocht. Voortaan had Storm een drievoudigen strijd te voeren - tegen ontevredenheid in het land, tegen altijd dreigende aanvallen van buiten, of hetgeen bijna zóó erg was, vrees daarvoor, en tegen verwaarloozing, voortgesproten uit onvoldaanheid, van de zijde der Bewindhebbers tehuis. Het was - zooals Netscher zegt van een iets vroegere periode in de geschiedenis van Essequebo - een ongelukkige cercle vic i e u x - verwaarloozing in het moederland verantwoordelijk voor de achterlijkheid der kolonie, en omgekeerd.

Reeds in 1744 had Storm naar huis geschreven:

„Den aanvoer van slaeven is een tweede gebrek dat seer veel verhindering aenbrengt tot een spoedigen aenwas deser Colonie.... Indien daer geen remedie toe wert gevonden sal sulx altijd een onoverwinnelijke hinderpael blijven daer alle voortgank mede sal worden gestuyt."

Maar gelijk hij in zijn latere leven zegt: ,ik heb het lot van Cassandra gehad". Zooals het met de slaven ging, ging het met de aanvoeren. Beroep volgde op beroep, doch latere brieven toonen dat zij allen zonder eenig resultaat waren wat betreft den geregelden aanvoer van de benoodigheden voor de kolonie.

Bij Storm's ambtelijke teleurstellingen kwamen zich in deze periode huiselijke rampen voegen die hem zwaar drukten. Op den laatsten dag van 1752 verloor hij zijn tweeden zoon, en acht jaren later, veertien maanden na elkander, stierven zijn gade en oudste zoon.

Troost in en afleiding voor zijn leed vond Storm in niets zoo zeer als in het genoegen dat hij beleefde van de opkomst van Demerary en dat genoegen kwam op een zeer gelegen tijdstip. Slechts eenige maanden na zijn terugkeer in 1752 schreef hij hoogst optimistisch over den vooruitgang der jonge nederzetting in 1746 begonnen en vermeldt hij ook de werkzaamheid van zekeren Gedney Clarke van Barbados en de aankomst van andere 
planters van andere eilanden. Het jaar daarna verheugt hij zich in het groot aantal toewijzingen gedaan voor aanleg van plantages en zegt hij dat de planters van Demerari,

„... alsoo verre het grootste getal uyt Engelsche of d'Engelsche tael verstaende bestonden ...."

vergunning gevraagd hadden godsdienst-oefeningen te mogen houden in hun eigen taal.

„... Dit versoek als ten hoogste prijsselijk heb ik haer ten eerste geaccordeert", zegt hij.

Hierover schrijft Netscher het volgende:

„Toen Storm de vestiging van Engelschen in Essequebo en Demerary, bevorderde, deed hij ongetwijfeld wijs, want zij brachten geld en energie mede, die beiden in de Kolonie ontbraken."

Storm was noch een Anglophile, noch een Anglophobe; hij sprak altijd over de Engelschen zooals hij die vond en de verschillende handelingen die hij tegen hen aannam of aanprees, werden bepaald niet door persoonlijke luim of gevoel, doch door de wisselende belangen der Compagnie, wier welvaart hij nauwgezet boven alles beschermde. Zeer spoedig na zijn aanstelling tot Commandeur schreef hij naar het vaderland:

„De Engelsche die sig hier reets neder hebben geset spaeren nog moeyte nog vlyt nog onkosten, en de meesten (d.w.z. van de overige planters) beginnen reets haer voorbeeld te volgen".

In zijn rapport dat hij in 1750 persoonlijk aan de Zeeuwsche Kamer overlegde, maakt hij vergelijkingen tusschen de Engelsche koloniën en zijn eigene met het oog om het voorbeeld dier koloniën te volgen, en wij hebben juist gezien hoe sympathiek hij handelde met het verzoek tot het aanstellen van een Engelschengeestelijke. Ofschoon hij herhaaldelijk in ronde woorden afkeurde de geneigdheid van Engelsche schippers om de betaling van de door de Nederlandsche Compagnie vastgestelde invoerrechten te ontduiken, erkent Storm openlijk dat zonder de aanvoeren door hen gebracht de kolonie er vaak treurig aan toe zou zijn geweest, en als hij in 1768, toen het smokkelen van slaven danig aan de orde was, verklaart dat het een weldaad voor de kolonie zou wezen, wanneer zij alle Engelschen kwijt kon zijn, erkent hij twee jaren later niettemin, toen hun verkiezing tot Raadsleden een onderwerp van geschil uitmaakte, dat het onjuist zou zijn hen van dat ambt uit te sluiten. 
In den brief, onmiddellijk volgende op dien, waarin hij van Clarke's ondernemingsgeest gewag maakte, noemt Storm, hem als 't ware bij zijn Bewindhebbers inleidende, hem

„.... een man van oordeel en groot vermoogen .... welke waarlijk een goed hart voor den welstand deser Colonie heeft".

En Clarke bevestigde door zijn gedragingen daarna volkomen Storm's meening aangaande hem op beide punten. Aangemoedigd door den Directeur-Generaal, legde hij niet alleen in 1753 plannen ,die de kolonie ten goede zouden komen, aan de Zeeuwsche Kamer over, doch stelde hij feitelijk vrijhandel voor aan dit door en door conservatieve lichaam. Maar dit gold natuurlijk als de reinste ketterij in Zeeland, en toch kwam het voorstel dienaangaande van een man door wiens tijdige hulp een tiental jaren later de Kolonie van ondergang gered werd.

Of Storm's vriendelijke verhouding met de Clarkes, vader en zoon, in haar begin, werd ingegeven door politiek, of dat deze slechts het uitvloeisel was van wederkeerige waardeering, is moeilijk uit te maken, doch de vriendschap was voor de kolonie van ver-strekkende gevolgen, om af te weren een ramp gelijk aan die welke in 1763 aan Berbice overkwam, en op een oogenblik toen de krachten, waarover Storm kon beschikken, te gering waren om het gevaar het hoofd te kunnen bieden. Toen het gevaar kwam was Storm diplomatiek genoeg zich niet in de eerste plaats om dadelijke hulp tot de Engelschen te wenden; alleen stelde hij Clarke, die groote bezittingen in Demerary had, in kennis met het gevaar dat de kolonie bedreigde en toen dit te duidelijker werd en hij, „na langdurige besprekingen en nadenkingen" besloten had den gouverneur van Barbados in naam der StatenGeneraal om de hulp van twee honderd man te vragen „bijaldien de stand van zaken die hulp na zorgvuldige overweging noodig maakt", maakte Clarke's optreden het voor Storm onnoodig aan dat voornemen gevolg te geven. Evenwel, niettegenstaande zijn volgende verklaring, gegeven in antwoord op de door de Compagnie gevraagde inlichtingen,

„direct secours heb ik noyt gevraegd, schoon eens op het punct hebbe gestaen om het te doen ...."

erkent Storm dankbaar, en dit meer dan eens, dat de hulp door de Engelschen gezonden

„.... naest God het behoud van Demerary is geweest".

Wanneer het verkeerd was zoowel planters als slaven te doen zien de zwakheid van he $:$ bewind, waaronder zij zich bevonden, 
dan was zulks zeker niet te wijten aan den man, die, reeds gebukt onder allerlei kleine administratieve zorgen, in dringende noodzakelijkheid de middelen gebruikte die het meest voor de hand lagen om de aan hem toevertrouwde belangen te beschermen, doch aan de Compagnie, wier bijkans misdadige veronachtzaming hem tot die uiterste noodzakelijkheid dreef. Wij hebben gezien hoe Storm altijd door aandrong op een sterk garnizoen; wij hebben gezien hoe hij telkens en telkens weer, doch altijd vergeefs, vroeg om voldoende zendingen van hetgeen noodig was, en men zou gedacht hebben dat de tijding van een slavenopstand de slapende Bewindhebbers zou hebben opgeschrikt. Storm stelde hen van dien opstand in kennis op 12 Maart 1763, doch schreef einde September dat:

„Het misnoegen wordt soo groot en algemeen, voor al in Demerary, dat voor de gevolgen vreese; het secours.... gekomen is soo gering naer de grootheyt van het gevaer."

En toch, terwijl Storm genoodzaakt was den kolonisten afschrift over te leggen van den brief, dien hij naar Nederland gezonden had, om hen te doen zien dat hij althans zijn plicht gedaan had, voegden de Bewindhebbers in Zeeland, na de bovengenoemde onvoldoende hulp te hebben gezonden, daaraan een brief toe, waarin zij schreven:

„.... sig flatteeren het gevaer voor den ontfangst derselve sal weezen verdweenen".

„Het is daer seer verre van daen", antwoordde Storm; het gevaer, Edele GrootAchtbare Heeren, is soo groot indien niet grooter als oyt geweest is."

Evenwel, eindelijk werd het gevaar, op wat inderdaad buitengewone uitgaven schenen, bezworen, en Storm en de kolonie ontkwamen aan de crisis, beiden een weinig zwakker door hetgeen van hen gevergd was.

Het laatste en kortste der drie tijdvakken, waarin Storm's koloniaal beheer door den loop der gebeurtenissen verdeeld werd, was niet, zooals aan den avond van een leven vol plichtsbetrachting gepast zou hebben, een tijdvak van vrede en kalmte, doch in schrille tegenstelling met hetgeen deze man verdiende en verlangde, een tijdvak van onophoudelijke moeilijkheden, waarvoor hij niet verantwoordelijk was en waarover hij ook slechts weinig invloed kon uitoefenen.

De druk van de ramp, die hem in 1763 zoo na had bedreigd, lag nog op hem in de lente van het volgend jaar, toen hij, mededeeling doende van het overlijden van zijn schoonzoon, schreef: 
„Mijne hooge jaren, swakke lichaems gesteltenisse, droefheden, wederwaerdigheden en continueele dwarsdryverijen, daerbij den last die nu mijne schouders alleen staat te drukken, sonder de geringste hulpe, maeken mij mijn ampt, het land, jae selver het leven wars en moede".

Doch ook toen was de beker nog niet vol. Een maand later schrijft hij:

„Uyt Demerary alhier weder gearriveert synde, hebbe.... ik tot mijn seer groot leedwesen de Heer Spoors (de Secretaris) bijnae van syn gesigt beroofd gevonden. .... Dit fatael ongeval.... brengt mij zoodanig in verwarring van bezigheden dat waerlijk geen doorkomen aen zie".

En in Augustus lezen wij de volgende aandoenlijke mededeeling:

„Het heeft den Almogende behaegt den 20sten July mijn zoon Gerard Johan in den ouderdom van omtrent 24 jaeren, uyt dit tijdelijke in syn eeuwig Koningrijke over te haelen, dus my van ses soonen niet meer overschiet als den jongste met 's Lands snauw van oorlog de Zephier naer Europa vertrokken. Smartelijke toevallen in mijn ouden dag, zoo kort op malkanderen gevolgt, maer men moet zig aen den wille des Alderhoogsten onderwerpen - Wie kan zijn hand afslaen, of tot hem zeggen, „Wat doet gij"?"

Dat de verwijzing naar zijn slechten gezondheids-toestand, in de eerste der drie gegeven aanhal ngen, niet te sterk was gekleurd, blijkt genoeg uit vroegere mededeelingen, dienaangaande, in 1760,1762 en 1763 gedaan, doch zóó onvermoeid was de geestkracht van dezen man, dat hetzelfde schip, dat den brief overbracht, waarin hij den dood van zijn zoon aankondigde, ook medevoerde, „een korte verhandeling betreffende planterschap” weliswaar vertaald, zooals hij zegt, ,in enkele vrije oogenblikken" - en een lang en belangwekkend rapport omtrent de handelplaatsen der Compagnie.

Maar, trots zijn groote geestkracht en onverflauwde belangstelling in de welvaart der kolonie, maakten een hernieuwde aanval van ziekte en de voortdurende verwaarloozing van de zijde der Compagnie Storm zóó wanhopig, dat hij in December 1765 schreef:

"Ik wensche van harte dat ik maer uyt de Colonie en in Europa was."

Het uitblijven van aanvoeren was ongetwijfeld zijn voornaamste grief; gevoeligheid over laster, hoe gering ook, een andere; huiselijk leed een derde, en ten slotte, ofschoon voor Storm de minste, toenemen van werkzaamheden, veroorzaakt door Spoor's blindheid en Van Bercheyk's dood. Het is dan ook niet verrassend 
te vernemen dat de Directeur-Generaal in 1766 opnieuw zijn verzoek om ontslag herhaalde, waarop hij reeds krachtig, doch te vergeefs, in 1763 had aangedrongen.

Maar ditmaal werd dit verzoek gedaan op een wijze zoo dringend mogelijk, want het werd niet slechts gericht tot de Zeeuwsche Kamer, doch ook onmiddellijk tot den Gouverneur-Generaal der West-Indische Compagnie, Willem V, Prins van Oranje. Herhaaldelijk wijst hij er Bewindhebbers, somtijds in roerende taal, op, dat hij niet bij machte is langer zijn last te dragen, doch de Kamer en Vergadering waren onderling twistende over de quaestie van vrijen handel met de kolonie, en dachten er weinig over hun ouden dienaar zijn taak te vergemakkelijken of hem daarvan te ontlasten, vóór het oogenblik daartoe gekomen zou zijn dat meer paste aan de langzaam-werkende Compagnie.

Ondertusschen namen Storm's plichten nog steeds toe en hij dacht er geen oogenblik aan die te verwaarloozen, ook al ontzonken hem de krachten in niet geringe mate. De vacature in het secretaris-schap na Spoor's blind worden in 1764 was nooit voldoende vervuld geworden, en het meeste van dat werk kwam terecht op de schouders van den Directeur-Generaal. Wij kunnen tusschen de regels zijner brieven door lezen dat Van der Heuvel bij lange na niet zulk een degelijk Commandeur van Demerary was als Van Bercheyck was geweest, en dat laatstgenoemde in geestkracht lang niet gelijk stond met Storm's eigen zoon, Jonathan, die vroeger dezen post bekleed had. Zoo werd Storm's hulp geringer, terwijl zij in dezelfde mate grooter had moeten worden. Hoe belachelijk dan ook te vernemen dat de mannen, die gedurende een lange reeks van jaren de kolonie systematisch hadden bekrompen in aanvoer van de noodige behoeften, slaven en verdedigings-middelen, die het politiek beschouwden, zéér tegen zijn wil, in dienst te houden een trouwen doch krukkenden dienaar, dat die mannen, slechts eenige maanden vóór zij hem uit een dienst van 35 jaren bevrijdden, hem beschuldigden van „slecht en onverantwoordelijk beheer", en hem verdachten van gemis aan ,eerlijkheid, oplettendheid en zuinigheid!”

Zelven geen slaven invoerende, gingen zij te keer tegen den onwettigen, doch onvermijdelijken invoer daarvan door de Engelschen; onvoldoende hoeveelheden levensbehoeften zendende, klagen zij er over dat hun slaven daarvan te weinig krijgen; zelfs niet de aller-noodzakelijkste grondstoffen zendende voor de plantages, geven zij hun onvoldaanheid te kennen over de opbrengst daarvan. 


\section{Netscher zegt:}

„In 1769 dienden de planters een request in aan de Staten-Generaal om vergunning van vrijen invoer van slaven, onder betaling eener zekere recognitie voor elken slaaf aan de W. I. Comp., maar in eene missive van de K 3 mer Zeeland van 19 Februari 1770 wordt aan Storm groot ongenoegen betuigd, dat hij bedoeld verzoek, „zoo ruïneus voor de Compagnie" had durven ondersteunen; terwijl hij in dezelfde missive werd berispt, over het oogluikend toelaten van den invoer eener lading vreemde slaven, ter waarde van $f 150.000$ (ongeveer 450 stuks)".

In September, 1771, schrijft Storm zelf:

„Er is geen spijker meer om iets vast te maken off de suykervaten toe te spijkeren".

En alweer in November van hetzelfde jaar:

„Den Directeur van Aechtekerke [een Compagnie's plantage] heeft nu die twee kostelijke springetijde van den evennagtlijn moeten voorbij laeten gaen sonder maalen wijl geen druppel olij heeft en ook in de geheele colonie geen te bekoomen is"'.

Kinderen, die een spel spelen, zouden meer logisch handelen dan deze Bewindhebbers deden, en toch nam de arme Storm al hun klachten ernstig op - inderdaad, in tragischen ernst. De toon in zijn antwoorden werd scherp, bitter soms, trots den eerbied, dien hij zijn meesters tot het einde toe bleef betoonen.

In November 1771 schrijft hij:

„Ik neme den Alweetende God tot getuygen dat ik al gedaan hebbe dat in mijn vermoogen is om het interest van de Comp. en Colonie te behartigen.

Gelieven U.E.G.A. de plantagien in staat te stellen, de plantagien zullen leeveren zoo goed als eene in de Colonie; nu dwingt mij de nood, nu moet ik paerden en muylezels koopen off al het ried laete verrotten".

En in dezelfde maand, opnieuw verwijzende naar de steeds bestaande schaarschheid van al het benoodigde, zegt hij:

„Voor mij is niets; ik koop wat mij noodig is en betael het selver. Maar d'andere bedienden, de slaaven, de plantagien, wat zal daar van worden? Behaegt het U.E.G.A. de plantagien met groote schreeden achteruyt te doen gaan ik wasch mijn handen daar van en zal het de voorzienigheyt overgeeven".

En bij al die ambtelijke zorgen, kwam opnieuw de dood slachtoffers eischen onder Storm's nog weinig overgebleven familieleden. In Juni 1771 schreef de Directeur-Generaal: 
„Het verlies van mijn oudste dochter heeft mij alles zoo wars en de. wereld zoo onverschillig gemaekt dat voorgenome hebbe onder affwagting van des Heeren bijstand tot het eynde zoo veel mogelijk mijn pligt te betragten, doen wat ik kan en voor de rest alles aan de goddelijke voorzienigheid over te laeten, en mij getrooste dat hier in dit ondermaensche geen rust konnende erlangen met die hoope en vertrouwe den Almogende mij goedertierentlijk in d'eeuwige ruste zal gelieven in te laeten, en dat zoo vroeg off zoo laet als het zijn heyligen Raad sal behaegen".

\section{En in Februari 1772 lezen wij:}

„Het den Almoogende God behaegt hebbende mijn waerde schoonzoon Johannes Bakker, raed van Politie en Commandant der Militie in dienste van U.E.G.A. den 19de dezer uyt het tijdelijke in zijn eeuwig Koningrijk over te haelen naer een zeer langduerige ziekte, hebbe ik mijn plicht geacht U.E.G.A. nog per deeze gelegentheyt van dit voor mijn dochter en mij zoo smartelijk geval kennis te geven. Ik verliese mijn regterhand en eenigste hulp welke nog hadde en U.E.G.A. een trouw, eerlijk en naerstig bediende"

Op 14 Juli 1772, dertien dagen nadat zijn ontslag in Zeeland was toegestaan, schreef Storm als volgt naar het vaderland:

„Ik ben U.E.G.A. ten hoogste verpligt voor de zoo genege wenschen weegen den staet mijner gesondheid .... De Heere zij gelooft en gepreesen, dat deselve eenigermaate verhoort zijn, want bevinde mij teegenswoordig door dezelfs zeegen beter als in lange jaaren geweest ben, tegens mijne en aller verwagting, uytgesondert d'aenhoudende jichtpijnen welke door de gewoonte bynae een tweede natuur zijn geworden, en het verlies van gehoor in een oor manqueert mij tegenwoordig weinig en vinde mijn memorie nog niet verzwakt en mijn gesigt zoo goed als oyt geweest is.

Hier uyt bevinde dat den goedertierene God veel maele kruys naar kragt en kragt naar kruys geeft, want zonder dien seegen hoe zoude ik het maken in zoo een chaos van besigheden zonder hulpe off bystand, bijnae alles selver moeten waerneemen? U.E.G.A. konnen onmogelijk beseffen hoe nagt en dag mijne gedagte over zoo veele en zoo onderscheyde zaeken moeten laeten gaan en daar bij het chagrijn niet alles te konnen verrigten wat gaerne wilde tot welzijn der Compagnie Colonie en genoege mijner meesters, maar niet konnende doen wat wel wilde, moet mij genoegen te doen wat ik kan".

In het begin van Augustus voorspelt hij moeilijkheden met de slaven, wijst op de oorzaak daarvan, en verklaart hij zijn menschelijke en staatkundige pogingen; om die te voorkomen. Maar de storm barstte los en nogmaals bevond zich de kolonie „op den rand van totalen ondergang".

Zooals ik reeds vroeger zei, was Storm vóór alles en in alles soldaat. Nooit ontmoeten wij in zijn brieven zulke krachtige taal dan wanneer hij in beduidende en indrukwekkende bewoordingen te vermelden heeft de maatregelen door hem genomen in de uiterste gevallen of in het gezicht van doodelijk gevaar. Een opstand 
der slaven - een altijd dreigend gevaar voor het bestaan eener kolonie in die dagen - of de vermelding van een Spaansch eskader langs de kust, en Storm, gemakkelijk een militair bevel op zich nemende, stelt zijn kleine bezetting op; weet zijn weinig militaire burgers op te wekken tot het doen van hun plicht, en schrijft ondertusschen aan de Bewindhebbers kalm maar dringend om hulp - die nooit kwam.

Zóó bleef Storm door en door soldaat tot het einde.

Zijn brieven van 29 Augustus en 24 September 1772, de laatste die hij schreef, zijn geheel wat dergelijke stukken in zulk een tijd moesten zijn - een duidelijke uiteenzetting van gebeurtenissen en van genomen maatregelen; prijzend degenen, die zich hadden onderscheiden door dapperheid; raadgevend wat betreft verdediging in de toekomst. Zijn opvolger, George Hendrik Trotz, kwam op 27 November 1772 op Fort Zeelandia aan en Storm's loopbaan was teneinde, salvis honoribus, zooals hij zoo vurig had gewenscht. Hij trok zich dadelijk terug op zijn plantage "Soestdijk" in Demerary, waar hij op 14 Augustus 1775 overleed in den leettijd van zeventig jare en tien maanden.

De twee deugden, die het sterkst op den voorgrond treden in Storm's karakter, zijn trouw en onomkoopbaarheid, en betere karaktertrekken dan deze kon geen gouverneur bezitten, gebaseerd als zij in zijn geval waren, de laatste op ware vroomheid, de eerste op een innig eergevoel, en bovendien werden deze onomstootelijke grondslagen nog krachtiger gemaakt door onbaatzuchtigheid, vlijt, matigheid in levenswijze en daarnevens door inspannend werk en eenvoudig optreden.

In 1746 schrijft Storm:

„Ik leve niet anders als borgerlijk, houde een seer gemeene jae slegte tafel daer self geen wijn als bij kerk of Court tijd wordt geschonken, in kleederen veel eerder onder mijn charackter als volgens het selve."

Eenige jaren later zegt hij:

„Echter leve in mijn huishouden als de geringste borger, mijne kinderen zoo wel als ik verre van in pracht uyt te steeken kleeden ons verre beneden onzen staet."

In 1762 bewoont hij, na 24 jaren dienst in de kolonie, een „seer kleyn" huys,

„Maer twee kamers 20 voeten vierkant en een voorhuys daer in synde”,

en een jaar later zegt hij:

„Ben genoodsaekt de raedsvergaderingen in het huys van den predikant te houden om dat in het mijne geen plaets daer toe is". 
In 1762 krijgen wij ook van hem de volgende merkwaardige verklaring:

„De provisien die U.E.G.A. mij hebben gelieven af te nemen om d. Hr. Spoors sijn aendeel te vermeerderen waeren het niet welke mij chagrineerde, wijl sulx waerlijk niet in staet waeren mij eenigsints chagrijn te veroorsaeken, want het bier, zeep, kaersen en speceryen alleen uytgesondert, hebbe ik voor mijn persoon weynig gebruik daer van; van de wyn hebbe noyt geloof ik al in al ses bottels gedronken, alle die geene welke in vaeten hier komt, hoe goet in syn soort bedorven synde, en is meest voor sieke gebruykt. Sterken drank drink ik niet, van de caes gebruyke mede niet, etc. Soo dat het niet was om deselve dat my beswaerde maer de vreeze dat dit een yutwerksel van U.E.G.A. ongenoegen was".

Zes jaar later geeft Storm zijn meening ten opzichte van een bescheiden, kalm leven op eenigszins snaakschen toon, wanneer hij zegt:

„Wanneer men regulier in zijne affairens te werk gaat en voor al den drank en die lekkere en verleydende Madera wijn menageerd en dezelve geen meester laet kan vrij meer uytgerecht worden als iemand zoude denken".

Eenvoudig en matig genoeg dus was dit leven, inspannend als het was, zooals reeds voldoende is aangetoond. Storm wist zeer goed dat weinig voldoening te verwachten was van het verschuiven van inspannenden arbeid of van werken zonder eenig stelsel, want in denzelfden brief, waaruit wij juist een aanhaling gaven, zinspeelt hij op beide ondeugden, terwijl hij juist een jaar later op hetzelfde onderwerp terug komt.

Toch was stoffelijke be ooning geenszins het doel van zijn streven. In 1763, na 25 jaren werken voor de Compagnie, kan hij tot zijn bewindhebbers zeggen:

„Rijkdom heb ik noyt bejaegt of gesogt, in soo een langen dienst noyt U.E.G.A. om eenige de minste augmentatie van gagie lastig gevallen".

In 1763, als hij om zijn ontslag vraagt, schrijft hij:

„Het is wel waer dat noyt mijn werk gemaekt hebbende om schatten te vergaderen ik het sekerlyk uyt den dienst synde niet ruym sal hebben, maer den goedertierene God op wien mijn vertrouwe stelle sal my, soo vertrouwe, wel goedgunstig tot mijn eynde brengen en voor mijne kinderen sorgen. Natura paucis contenta".

Bij een zelfde gelegenheid zegt hij in 1766:

„Pensioen of eenige gagie of provisien vraeg ik niet wijl sulx seer onredelijk soude weeze d'Ed. Compe. reets lasten ten overvloede draegende". 
In 1767 vermindert hij uit eigen vrijen wil het aandeel der rechten op eigendoms-bewijzen, waarop hij recht had, met een derde, en in 1769, als hij zich beklaagt over den druk van zijn arbeid, vernemen wij uit zijn pen de volgende uitspraak:

„Alhoewel het by interim waernemen van het venduemeesters ampt nog al wat opbrengt en men gemeenlijk segt het geld versoet den arbeyd vind sulx by my geen plaets. Nooyt geldgierig geweest zijnde en vergenoegd met myn daagelijks brood (daar wij alleen om bidden) verligt my dit niet".

Inderdaad, baatzuchtig kan niet geweest zijn de man, die, terwijl hij elken dag de toestemming op zijn verzoek tot ontslag verwachtte, in 1771 schreef:

„Dit soude een kostelijk jaar voor de venduemeester weesen [dit ambt bekleedde hij zelf], zijn leeges bedragende over de 15.000, maar vreese, niet sonder reede, daar wel twee derde van gedefalqueert sullen moeten worden door wanbetaling en protesten. Ik kan over my niet krijgen menschen welk buyte haar schuld in het agterspit zyn geraekt totaliter te ruineeren en buyten staet te stellen om oyt weeder op te koomen en wilde niet gaaren met den vloek van zoodanige ten grave daelen. Myne kinderen hebbe, Gode loff, als 't de Heere 't gelieve te zeegenen een stuk brood en mooge verder haar best doen en op hem vertrouwen die alles oppermagtig regeert. $\mathrm{Zij}$ mogen met my zeggen:

$$
\begin{aligned}
& \text { ' } k \text { Wensch rijkdom nog gebrek } \\
& \text { Ik wensche spaade en vroeg } \\
& \text { Te weynig nog te veel, } \\
& \text { Genoeg is mij genoeg." }
\end{aligned}
$$

Het is niet verwonderlijk dat de bezittingen van een man met dergelijke gevoelens - en Storm laat zich op dit punt open genoeg jegens zijn lastgevers uit - vrij armzalig waren, in aanmerking genomen zijn langdurige loopbaan en de vele posten die hij te vervullen had.

Ofschoon de bewijzen voorhanden zijn dat Storm, toen hij in de kolonie kwam niet geheel en al onbemiddeld was, moest hij toch grootendeels bestaan van zijn salaris van 500 gulden 's jaars plus enkele emolumenten, te oordeelen althans naar zijn klacht over geringe inkomsten, toen hij in 1746 de eerste maal zijn ontslag vroeg. Een vermeerdering van zijn salaris met 300 gulden werd hem in 1748 toegewezen, maar,

,zulks is uyt een bysondere gunst en edelmoedigheyt door U.E.G.A. ongevraegt gedaen."

zegt Storm in 1763, wanneer hij in spijt van het feit dat zijn "onkosten sonder comperatie veel grooter en zwaerder zijn" dan 
die van zijn voorganger waren - zooals hij duidelijk aantoont mededeelt dat hij uit eigen middelen heeft gekocht.

„een huys dat hier juyst te koop quam voor elfhondert guldens waer aen nog wel soo veel aen reparatien te kosten zal moeten leggen".

Zulk een aankoop moet natuurlijk gedaan zijn uit eigen middelen of uit de voordeelen verkregen van de plantage die elke dienaar der Compagnie met haar toestemming mocht bezitten. Maar in den loop der tijden kwam Storm in nieuwe finantieele moeilijkheden, waarvan hij plichtmatig, doch te vergeefs, den Bewindhebbers in het vaderland in kennis stelde.

In 1765 schrijft hij:

„Het is mij volstrekt ondoenlijk jegenswoordig met mijne inkomsten te bestaen en moet alle jaeren achteruyt raeken synde nu reets over de drie duysend guldens aen mijn correspondent ten achteren....

De plantagie Soesdyk het eenigste zoo te zeggen dat wij hebben, voor d'eene helft de weduwe en haer kinderen, voor d'andere helft mijne overige kinderen toebehoorende jaer voor jaer te beswaeren, zoude nog voor God nog voor de menschen verantwoordelijk wesen.

Is het dan niet beter mijn huys en land alhier te verkopen, de schult aen d'Heer Bruyn [Pieter de Bruyn, zijn correspondent in Middelburg] af te doen en stil op de plantagie te gaen leven en zoo mager als het valt zig voor de weynig levenstyd die nog overig hebbe te behelpen?"

Alweer in 1769 verzekert hij zijn meesters:

„Daar is geen ampt in beyde riviere van den Directeur generael aff tot den geringste toe (except den vendue meester) waar van d'ampten elk naer zijn rang en qualiteyt fatsoenlijk kan bestaan en iets overgaaren zoo zij niet iets anders daar bij bij de hand neemen, 't sij de negotie, administratien, eygen plantagien, 't sij wat anders. Bij voorbeeld een commandeur van Demerary, om van booven aan te beginnen, kan die van $f 30$ per maand neevens zijn rantsoen en provisien bestaan? Volstrekt niet, Ed.Gr. Achb. Heeren, het is er seer verre van daan en als niets van syn selven en hadden en niet ten uyterste vigileerde om op een eerlijke wyze een stuyver te winnen, sou magere soepe kooken".

En als hij in Maart 1771, het jaar voorafgaande aan dat waarin hij zijn ontslag kreeg, schrijft, verklaart hij openlijk als volgt:

Ik hebbe de eer gehad nu over de 34 jaaren U.E.G.A. te dienen; waar is mijn rijkdom welke overgelegt hebbe? Ik besitte niets als de halve plantagie Soestdijk welke door de onvermoeyde vlyd en arbeid mijner twee schoonzonen Bercheyk en Van den Heuvel in staat is geraakt om mij in mijn ouden dag onder des Heeren zeegen een stuk brood te geeven".

Dat er andere middelen waren om zich schadeloos te stellen ten 
aanzien van de overdrevene zuinigheid der Compagnie, blijkt wel uit enkele eenvoudige doch beteekenisvolle woorden, die Storm naar het vaderland schreef in November 1770.

„Een seeker heer is hier gekomen om te trachten die pot te smooren [een geval van ingesmokkelde slaven] en heeft mij ses duysent guldens aangebooden het welke van de hand geweesen hebbe".

Maar het zich begeven op dergelijke kronkelpaden strookte niet met het karakter van iemand, die zich vroomheid en rond handelen tot een eer rekende, en die eer zelve „kostbaarder achtte dan iets anders".

Bijkans elke bladzijde in Storm's brieven bewijst welk een beteekenis godsdienst in zijn leven bezat en hoe vóór alles zijn eer hem lief was. Doch gelijk in alle menschelijk leven had ook hij de ondeugden voortgesproten uit zijn deugden, want zijn eerbesef leidde bij hem tot deze enkele zwakheid - overgevoeligheid ten opzichte van de meening der wereld.

„Mens sibi conscia recti hoeft sig het lasteren niet aen te trekken", schreef hij zelf in 1767, en inderdaad, minder aandacht voor de kleinzielige spijtigheden en praatjes, gesproten uit eigenbelang, van de onbeduidende menschen om hem, zoude zijn geest en pen meer vrijheid gegeven hebben zich bezig te houden met belangrijker vraagstukken en de toekomst, die hij bezig was te scheppen - zou ijn lichaam meer geschonken hebben van de rust, die het in een tropisch klimaat behoefde. Wanneer hij, om slechts iets te noemen, in 1751, toen hij in de kolonie was teruggekeerd, zijn ooren gesloten had gehouden voor al hetgeen hij toen hoorde en krachtig zich had verzekerd dezelfde autoriteit, welke hij twee jaren te voren had bezeten, veel zou anders geweest zijn in het beheer, waarmede hij te doen had. Nochtans, de geweldige moeilijkheden waartegen hij te vechten had door de schromelijke laksheid der Compagnie en de déloyaliteit der kolonisten, mogen nooit uit het oog worden verloren.

$\mathrm{Na}$ het einde zijner ambtelijke loopbaan geraakte Storm allengs in vergetelheid, terwijl anderen de vruchten, en gedurende langen tijd den roem van zijn levenstaak genoten. Vandaar dan ook dat voor hem zeker gelden de woorden, door hem zelf zoo vaak toegepast op zijn daden ten bate der kolonie:

Hos ego versiculos feci, tulit alter honores. 